\title{
Biaya Dan Pendapatan Usahatani Pembenihan Lele Sangkuriang (Clarias gariepinus) \\ (Studi kasus Di Desa Ngijo Kecamatan Gunungpati Kota Semarang)
}

\author{
Fees And Business Income Sangkuriang Lele Seeds (Clarias gariepinus) \\ (Case study in Ngijo Village, Gunungpati District Semarang City)
}

\author{
Sulistyowati ${ }^{1)}$ \\ 1) Staf Pengajar Sekolah Tinggi Ilmu Pertanian Farming Semarang \\ e-mail: watisulis379@gmail.com
}

\begin{abstract}
ABSTRAK
Penelitian ini bertujuan untuk: 1) mengetahui besarnya biaya, penerimaan, dan pendapatan dari petani pembenihan ikan lele sangkuriang di desa Ngijo kecamatan Gunungpati, 2) mengkaji usia, pendidikan dan luas lahan terhadap pendapatan. Penelitian dilakukan pada bulan Oktober- Desember 2017. Metode penelitian digunakan metode deskriptif dan sensus artinya populasi sejumlah 32 orang semua dipakai sebagai responden. Data yang dikumpulkan dalam penelitian ini adalah data kuantitatif dan data kualitatif, sedangkan sumber data terdiri dari data primer dan sekunder. Hasil penelitian menunjukkan 1) Biaya produksi rata-rata per $\mathrm{m}^{2}$ pembenihan ikan lele sangkuriang, sebesar $\mathrm{Rp} 4.927 .676,92$, penerimaan sebesar Rp 13,843,384.62,- dan pendapatan sebesar 8.915.707,69,-, biaya produksi (biaya indukan, biaya pakan, biaya tenaga kerja dan biaya listrik) berpengaruh sangat signifikan terhadap pendapatan; 2) Usia petani pembenihan ikan lele sangkuriang rata-rata usia tua, dengan pendidikan yang cukup baik dengan luas lahan $\pm 100 \mathrm{~m}^{2}$. Kesimpulan 1) Penggunaan biaya produksi berkaitan dengan luas lahan, semakin luas lahan semakin besar biaya produksi sehingga pendapatan juga semakin meningkat, 2) Pada umumnya petani pembenihan ikan lele sangkuriang di desa Ngijo usianya tergolong usia tua, pendidikannya tergolong cukup sehingga lebih cepat menguasai dan menerapkan teknologi yang diterima dengan luas kepemilikan lahan yang tidak begitu luas \pm 100 $\mathrm{m}^{2}$.
\end{abstract}

Kata kunci : Lele sangkuriang, pembenihan, pendapatan usahatani

\section{ABTRACT}

This study aims to: 1) determine the amount of costs, revenues, and income from sangkuriang catfish hatchery farmers in the village of Ngijo, Gunungpati sub-district, 2) assess the age, education and land area of income. The research method used descriptive and census methods which means a population of 32 people are all used as respondents. Data collected in this study are quantitative and qualitative data, while data sources consist of primary and secondary data. The results showed 1) The average production cost per $m 2$ of sangkuriang catfish hatchery, amounting to $R p 4,927,676.92$, revenue of $R p 13,843,384.62$ and income of 8,915,707.69, production costs (broodstock, costs feed, labor costs and electricity costs) have a very significant effect on income; 2) The average age of farmers sangkuriang catfish hatchery in old age, with a fairly good education with an area of $\pm 100 \mathrm{~m}^{2}$. Conclusions: 1) The use of production costs related to the area of land, the greater the area of land the greater the cost of production so that income is also increasing, 2) In general, sangkuriang catfish hatchery farmers in Ngijo village are classified as old age, their education is quite sufficient so that it is faster mastering and applying technology that is accepted with a land area of less than $\pm 100 \mathrm{~m}^{2}$.

Keywords: sangkuriang catfish, hatchery, farm income 


\section{PENDAHULUAN \\ A. Latar Belakang \\ Lele sangkuriang (Clarias} gariepinus) merupakan salah satu jenis ikan air tawar yang sudah di budidayakan secara komersial oleh masyarakat di Desa Ngijo kecamatan Gunungpati Kota Semarang. Berdasarkan keunggulan Lele Dumbo hasil perbaikan mutu diberi nama "Lele Sangkuriang". Lele hasil budidaya. menghasilkan lele Sangkuriang kelas benih besar. Untuk m e n g h indari penurun a n pertumbuhannya maka perlu mengikuti kaidah- kaidah proses produksi sesuai dengan petunjuk pembenihan lele Sangkuriang.

Usaha pembenihan ikan lele sangkuriang banyak digemari penggiat perikanan dikarenakan memiliki potensi dan resiko yang relatif sebanding dengan hasilnya, modal yang dikeluarkan tidak terlalu besar, namun jika dikerjakan secara serius hasilnya akan sangat memuaskan. Pertimbangan lain dipilihnya usaha pembenihan ikan lele sangkuriang ini antara lain karena daya serap pasar yang masih tinggi dan potensi kebutuhan akan benih ikan lele sangkuriang masih tinggi dan potensi dibutuhkan untuk budidaya pembesarannya mengingat masyarakat Indonesia gemar makan ikan untuk memenuhi kebutuhan akan protein hewaninya tetapi dengan memilih ikan yang harganya masih terjangkau.

Desa Ngijo adalah salah satu desa di Kecamatan Gunungpati Semarang, luas wilayah Desa Ngijo 318.762 ha. Desa Ngijo mayoritas penduduknya adalah petani, dimana kegiatan pertaniannya mencakup peternakan perikanan (terutama pembenihan) dan pertanian tanaman pangan ( Data Demografi Desa Ngijo, 2016)

Keunggulan dari lele sangkuriang antara lain, pertumbuhan lele sangkuriang lebih cepat di banding lele dumbo biasa. Pada tahap pendederan, pertumbuhan lele sangkuriang mencapai $29,26 \%$, sementara lele dumbo biasa hanya $20,38 \%$. Dengan pertumbuhan lebih cepat, lele sangkuriang dapat lebih cepat di panen di banding lele dumbo, selain itu daya tetas telur lele sangkuriang lebih tinggi di banding lele dumbo. Tingkat fekunditasinya dua kali lebih tinggi fekunditasi dari lele sangkuriang mencapai 40.000-60.000 butir/kg induk, sedangkan lele dumbo biasa hanya 20.000-30.000 butir/kg bobot induk (Sunarma 2004).

Potensi perikanan tersebut, salah satu jenis usaha perikanan yang banyak di lakukan oleh beberapa masyarakat di Desa Ngijo Kecamatan Gunung pati adalah usaha budidaya pembenihan ikan dalam kolam. Desa Ngijo Kecamatan Gunungpati merupakan salah satu wilayah yang memiliki potensi perikanan baik, khususnya perikanan darat (tawar). Potensi tersebut antara lain adalah topografi tanah, mutu air dan iklim yang menunjang tingkat keberhasilan dalam bidang budidaya perikanan darat (pembenihan, pendederan dan pembesaran). Hal ini yang menunjang Desa Ngijo Kecamatan Gunung pati sebagai wilayah perikanan di Indonesia adalah letak Desa Ngijo yang mudah di jangkau oleh kecamatan disekitarnya. Oleh karena itu, pemasaran produk hasil perikanan dapat di distribusikan dengan cepat.

Wilayah Desa Ngijo strategis karena dekat dengan pasar, jalan yang mudah di jangkau membuat wilayah Desa Ngijo ini, sangat baik untuk pembenihan ikan lele khususnya penyediaan benih bagi petambak lele di daerah Jawa Tengah.

Berdasarkan fenomena tersebut, penulis akan menghitung mengenai biaya, penerimaan dan pendapatan petani pembenihan ikan lele sangkuriang (Clarias gariepinus) di Desa Ngijo Kecamatan Gunungpati Kota Semarang. 
Pada lahan berapa $\mathrm{m}^{2}$ kah yang nantinya akan memberikan keuntungan atau pendapatan maksimum bagi petani ikan. Pendapatan tersebut diperoleh berdasarkan perhitungan antara penerimaan yang diperoleh petani dari hasil panen benih ikan dengan biayabiaya yang dikeluarkan.

\section{MATERI DAN METODE}

Usahatani merupakan kegiatan berbudidaya dengan mengalokasikan sumber-sumber daya seperti tanah/lahan, tenaga kerja, modal, dan air untuk memperoleh pendapatan guna memenuhi kebutuhan hidup. $\mathrm{Hal}$ ini seperti yang telah diungkapan Soekartawi (2002) bahwa usahatani adalah ilmu yang mempelajari bagaimana seseorang mengalokasikan sumber daya yang ada secara efisien untuk tujuan memperoleh keuntungan yang tinggi pada waktu tertentu. Pentingnya kebutuhan benih lele yang sangat besar agar dapat memenuhi kebutuhan benih bagi petani ikan (Dardiani dan Sary, 2010).

\section{Biaya Usahatani}

Biaya merupakan jumlah nominal uang tertentu yang dikeluarkan oleh pelaku ekonomi untuk memperoleh barang dan/atau yang diperlukan. Biaya dalam konteks penelitian ini dibedakan menjadi biaya tetap dan biaya tidak tetap, dimana biaya tetap terdiri dari biaya kolam, pompa,, dan peralatan lain dan biaya tidak tetap terdiri dari biaya indukan, pakan, tenaga kerja, dan listrik. Harga benih ikan lele yang relatif stabil sehingga pembenihan ikan lele banyak diminati oleh warga desa Gowok Jogyakarta (Darseno, 2010).

\section{Metode Analisis}

Alat analisis yang digunakan dalam penelitian ini adalah statistik deskriptif dan uji F. Statistik deskriptif digunakan untuk membantu memecahkan masalah mengenai besaran biaya, dan penerimaan dari usahatani petani pembenihan ikan yang dalam hal ini membuat benih ikan lele sangkuriang. Pendapatan usaha tani (net farm income) didefinisikan sebagai selisih pendapatan kotor usaha pembenihan lele dan pengeluaran total usaha pembenihan lele.

1. Pendapatan merupakan selisih usaha dapat digunakan untuk mengukur imbalan yang diperoleh ditingkat keluarga pembenih dari segi penggunaan faktor-faktor produksi, pengelolaan dan modal (Soekartawi, 2002).

Jadi pendapatan usaha tani dapat dirumuskan sebagai berikut :

$\mathrm{Y}=\mathrm{TR}-\mathrm{TC}$

Dimana:

$$
\begin{aligned}
\mathrm{Y}= & \text { pendapatan usahatani } \\
& \mathrm{pem} \mathrm{b} \text { e } \mathrm{n} \mathrm{h} \text { a } \mathrm{n} \text { I e I e } \\
& \text { sangkuriang(Rp) } \\
\mathrm{TR}= & \text { Total penerimaan usahatani } \\
& \mathrm{p} \text { e m b e } \mathrm{n} \mathrm{i} \text { a } \mathrm{n} \text { I e I e } \\
& \text { sangkur(Rp) } \\
\mathrm{TC}= & \text { Total biaya usahatani } \\
& \text { pembenihan lele sangkuriang } \\
& (\mathrm{Rp})
\end{aligned}
$$

Pendapatan pembenihan dinyatakan lebih besar apabila usaha pembenihan yang dilakukan efisien, dalam artian penggunaan faktor produksi menggunakan biaya minimal untuk menghasilkan produksi benih yang maksimal. Karena keberhasilan petani tidak hanya diukur dari besarnya hasil produksi, akan tetapi juga dilihat dari besarnya biaya dalam proses selama produksi berlangsung. Hal ini dikarenakan dalam proses produksi sangat menentukan pendapatan bersih petani.

2. Uji Simultan (Uji F) digunakan untuk mengetahui apakah faktor sarana produksi biaya indukan dan pakan, tenaga kerja dan listrik (X) secara 
bersama-sama berpengaruh secara signifikasi terhadap pendapatan $(\mathrm{Y})$. Hipotesis statistik yang digunakan adalah sebagai berikut:

a. $\mathrm{Ho}: \mathrm{bi}=\mathrm{b} 2=\mathrm{b} 3=0$ artinya tidak terhadap pengaruh yang signifikan dari faktor sarana produksi terhadap pendapatan perbenihan lele sangkuriang.

b. Ha: $b i \neq 0$ artinya terhadap pengaruh yang signifikan dari variabel independen terhadap pendapatan pembenihan ikan lele.

Kriteria Uji :

1) Jika $F_{\text {hit }}>F_{\text {tab }}$, atau probabilitas $\alpha<0,05$ maka $\mathrm{Ho}$ ditolak dan $\mathrm{Ha}$ diterima

2) Jika $F_{\text {hit }}<F_{\text {tab }}$, atau probabilitas $\alpha>0,05$ maka Ho diterima dan Ha ditolak

3. Uji Parsial (Uji-t), digunakan untuk menguji sebuah variabel faktor sarana produksi $(\mathrm{X})$ benar-benar memberikan kontribusi terhadap variabel terkait pendapatan $(Y)$. Pengujian ini akan diketahui jika secara terpisah suatu variabel $X$ masih memberikan pengaruh signifikan terhadap variabel Y.

Hipotesis yang digunakan adalah sebagai berikut:

1) Ho:b = 0 artinya faktor sarana produksi bukan merupakan penjelas yang signifikan berpengaruh terhadap variabel pendapatan.

2) Ho $: b \neq 0$ artinya variabel vaktor sarana produksi merupakan penjelas yang signifikan berpengaruh terhadap variabel pendapatan.

Uji sebagai berikut :

1) Terima Ho jika $t_{\text {hit }}<t_{\text {tab }}$ atau probabilitas $\alpha>0,05$ maka koefisien regresi (b) tidak nyata

2) Tolak Ho jika $t_{\text {hit }}>t_{\text {tab }}$ atau probabilitas $\alpha<0,05$ maka koefisien regresi (b) nyata.

\section{Hipotesis :}

a. Diduga usahatani pembenihan ikan lele sangkuriang di desa Ngijo meningkatkan pendapatan.

b. Diduga faktor sarana produksi biaya indukan dan pakan, tenaga kerja dan listrik secara bersama-sama berpengaruh secara signifikasi terhadap pendapatan.

c. Diduga faktor sarana produksi (biaya indukan dan pakan, tenaga kerja dan listrik) benar-benar memberikan kontribusi terhadap pendapatan $(Y)$.

\section{Pendapatan (Y)}

Pendapatan merupakan pendapatan bersih usahatani pembenihan lele sangkuriang selama satu periode pembenihan. Pendapatan bisa dihitung dari selisih pendapatan kotor dan biaya produksi.

\section{Penerimaan}

Merupakan hasil perkalian antara jumlah benih yang dihasilkan dengan harga jual ikan lele sangkuriang per ekor. Penerimaan pada usahatani pembenihan lele sangkuriang dapat dihitung dengan rumus sebagai berikut (Soekartawi, 2002).

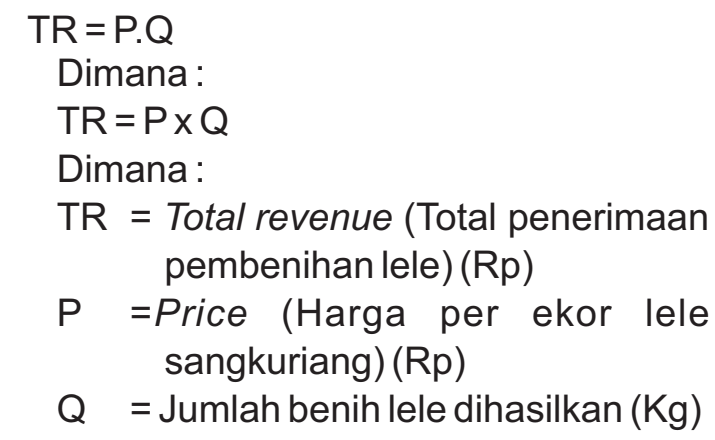




\section{HASIL DAN PEMBAHASAN Deskripsi Sample Penelitian}

Karakteristik petani pembenihan ikan dalam penelitian ini dibagi menjadi empat karakteristik sosial ekonomi. Karakteristik tersebut meliputi :

a.Usia

Tabel 1. Jumlah Responden Berdasarkan Usia

\begin{tabular}{|c|c|c|}
\hline Kelompok Usia (tahun) & Responden (orang) & Persentase (\%) \\
\hline 1. $21-30$ & 5 & 15,62 \\
\hline 2. $31-40$ & 11 & 34,37 \\
\hline 3. $\geq 41$ & 16 & 50 \\
\hline Total & 32 & 100 \\
\hline
\end{tabular}

Tabel 1. menunjukkan pengelompokan petani pembenihan ikan lele sangkuriang berdasarkan usia. Terlihat bahwa petani pembenihan ikan lele sangkuriang sebagian besar berusia diatas 41 tahun (lebih berpengalaman).

Berdasarkan hasil penelitian yang diperoleh, komposisi umur petani responden berkisar antara 21-55 tahun dengan rata-rata umur petani responden adalah 41 tahun. Mantra (2004) menyatakan bahwa umur produktif secara ekonomi dibagi menjadi 3 klasifikasi, yaitu kelompok umur 0-14 tahun merupakan usia belum produktif, kelompok umur 1564 tahun merupakan kelompok usia produktif, dan kelompok umur di atas 65 tahun merupakan kelompok usia tidak lagi produktif. Menurut Hawkins (1999) dalam penelitiannya mengemukakan bahwa orang yang berumur muda atau berusia produktif ternyata tidak menunjukkan lebih inovatif dibanding yang berumur lebih tua.

Usia produktif merupakan usia ideal untuk bekerja dan mempunyai kemampuan untuk meningkatkan produktivitas kerja serta memiliki kemampuan yang besar dalam menyerap informasi dan teknologi yang inovatif di bidang pertanian. Usia produktif tersebut merupakan usia ideal untuk bekerja dengan baik dan masih kuat untuk melakukan kegiatan-kegiatan di dalam usahatani.

Dalam pengembangan usahatani perlu adanya dorongan kepada para petani agar mau mengubah cara berpikir, cara kerja dan cara hidupnya yang lama dengan cara-cara baru yang lebih sesuai dengan perkembangan zaman dan perkembangan teknologi pertanian, sehingga diharapkan akan terjadi perubahan dan peningkatan perilaku petani dalam meningkatkan produktivitas usahatani.

\section{a.Tingkat Pendidikan}

Tabel 2. Jumlah Responden Berdasarkan Tingkat Pendidikan

\begin{tabular}{ccc}
\hline Tingkat Pendidikan & Responden (orang) & Presentase (\%) \\
\hline SD & 8 & 25 \\
SMP & 14 & 43,75 \\
SMA & 10 & 31,25 \\
\hline Total & 32 & 100 \\
\hline
\end{tabular}

Sumber : Data Primer diolah, 2020 
Berdasarkan Tabel 2. diatas menunjukkan tingkat pendidkan petani pembenihan ikan lele sangkuriang di desa Ngijo. Petani pembenihan ikan lele sangkuriang mayoritas tingkat pendidikan SMP $43,75 \%$ atau 14 orang dan SMA $31,25 \%$ atau 10 orang. Tingkat pendidikan paling sedikit pada tingkat SD sebanyak $25 \%$ atau 8 orang sehingga petani cukup mudah menyerap perkembangan pengetahuan.
Tingkat pendidikan akan mempengaruhi pengetahuan petani. Petani yang memiliki jenjang pendidikan tinggi pada umumnya akan lebih cepat menguasai dan menerapkan teknologi yang diterima dibandingkan dengan petani yang berpendidikan rendah. Menurut Sulaiman (2018) bahwa tingkat pendidikan menimbulkan peningkatan pendapatan usahatani.

\section{a.Kepemilikan Luas Lahan Kolam}

Tabel 3. Luas Lahan Kolam Pembenihan Ikan

\begin{tabular}{ccr}
\hline Luas lahan $(\mathrm{m} 2)$ & Responden (orang) & Presentase (\%) \\
\hline $70-146$ & 13 & 40,62 \\
$147-223$ & 11 & 34,37 \\
$224-300$ & 8 & 25 \\
\hline Total & 32 & 100 \\
\hline
\end{tabular}

Sumber : Data Primer diolah, 2020

Tabel 3. menunjukkan jumlah petani pembenihan ikan lele sangkuriang berdasarkan kepemilikan lahan yang dilihat dari luasnya. Sebagian besar petani pembenihan ikan lele seluas 30 $100 \mathrm{~m}^{2}$, yaitu sebesar 13 orang atau $40,62 \%$. Petani yang jumlahnya paling sedikit adalah petani yang memiliki lahan seluas lebih dari $190 \mathrm{~m}^{2}$.

\section{Pembahasan Hasil Penelitian}

Hasil analisis mengenai biaya rata-rata per $\mathrm{m}^{2}$ usahatani pembenihan ikan lele sangkuriang di desa Ngijo menurut luas lahan

Tabel 4. Biaya Rata-rata per $\mathrm{m}^{2}$ Usahatani Pembenihan Ikan Lele Sangkuriang Di Desa Ngijo (dalam rupiah).

\begin{tabular}{cccr}
\hline Luas lahan $\left(\mathrm{m}^{2}\right)$ & $\begin{array}{c}\text { Biaya Tetap } \\
\text { Rata-rata per } \mathrm{m}^{2}\end{array}$ & $\begin{array}{c}\text { Biaya Variable } \\
\text { Rata-rata per } \mathrm{m}^{2}\end{array}$ & $\begin{array}{c}\text { Biaya Produksi } \\
\text { Rata-rata per } \mathrm{m}^{2}\end{array}$ \\
\hline $70-146$ & $822.123,08$ & $4.105 .553,85$ & $4.927 .676,92$ \\
$147-223$ & $1.126 .818,18$ & $5.060 .881,82$ & $6.187 .700,00$ \\
$224-300$ & $2.010 .968,75$ & $8.530 .731,25$ & $10.541 .700,00$ \\
\hline Sumber : Data Primer diolah, 2020 & &
\end{tabular}

Biaya produksi rata-rata per $\mathrm{m}^{2}$ untuk pemijahan ikan lele sangkuriang di desa Ngijo memiliki nilai yang semakin meningkat seiring dengan semakin luasnya lahan yang dimiliki. Biaya produksi rata-rata per $\mathrm{m}^{2}$ terkecil ada pada petani pembenihan ikan lele sangkuriang, yaitu sebesar
Rp 4.927.676,92 dengan luas lahan kurang dari $100 \mathrm{~m}^{2}$. Hal ini sesuai pendapat Sulaiman (2018) luas lahan akan menimbulkan peningkatan pendapatan usahatani atau dapat dikatakan bahwa jika luas lahan meningkat, maka pendapatan usahatani meningkat pula. 
Tabel 5. Penerimaan Rata-rata per $\mathrm{m} 2$ Usahatani Pembenihan Ikan lele sangkuriang di desa Ngijo

\begin{tabular}{cccc}
\hline $\begin{array}{c}\text { Luas lahan } \\
(\mathrm{m} 2)\end{array}$ & $\begin{array}{c}\text { Rata-rata Produksi } \\
\text { benih ikan (ekor) }\end{array}$ & $\begin{array}{c}\text { Harga benih per ekor } \\
(\mathrm{Rp})\end{array}$ & $\begin{array}{c}\text { Rata-rata Penerimaan } \\
\text { per m2 (Rp) }\end{array}$ \\
\hline $70-146$ & $166,633.33$ & 90 & $13,843,384.62$ \\
$147-223$ & $225,831.82$ & 90 & $20,324,863.64$ \\
$224-300$ & $344,937.50$ & 90 & $31,044,375.00$ \\
\hline \multicolumn{2}{l}{ Sumber : Data Primer 2017, diolah }
\end{tabular}

Sumber : Data Primer 2017, diolah

Tabel 5. menunjukkan penerimaan rata-rata per $\mathrm{m}^{2}$ yang diperoleh petani pembenihan ikan lele sangkuriang terendah sebesar $\mathrm{Rp}$ $13,843,384.62$,- pada kepemilikan ratarata luas lahan kurang dari $100 \mathrm{~m}^{2}$, semakin luas lahan penerimaan petani pembenihan ikan lele sangkuriang semakin meningkat, hal ini sesuai pendapat menurut Yuvitasari,D et all, (2017) bahwa penerimaan juga dipengaruhi oleh faktor sosial, dimana semakin tinggi tingkat faktor sosial petani maka semakin tinggi tingkat penerapan teknologi budidaya . Hal ini dibuktikan bahwa faktor sosial yang dimiliki petani dari segi pengalaman berusaha tani, penggunaan media massa, tingkat kosmopolitan, pendidikan nonformal, pendidikan formal, dan lingkungan sosial yang pernah petani tempuh dan lakukan masih memiliki peranan dalam penerapan teknologi budidaya sehingga penerimaan juga akan semakin meningkat.

Berdasarkan hasil uji $F$ menunjukan bahwa biaya produksi (biaya indukan, biaya pakan, biaya tenaga kerja dan biaya listrik) berpengaruh sangat signifikan terhadap pendapatan ( $F$ hitung $=61,112$ dengan sig $F=0,000)$. Berdasarkan dari hasil uji-t semua biaya produksi sangat signifikan terhadap pendapatan pada usaha pembenihan ikan lele sangkuriang, karena diperoleh nilai probabilitas (sig. 2 tailed $=0,000$ ) adalah sangat signifikan karena lebih kecil dari 0,05.

\section{KESIMPULAN DAN SARAN}

Berdasarkan analisa data yang telah dilakukan, pada penelitian pemnbenihan lele sangkuriang di Desa Ngijo Kecamatan Gunungpati Kota Semarang dapat disimpulkan sebagai berikut:

1. Penggunaan biaya produksi berkaitan dengan luas lahan, semakin luas lahan semakin besar biaya produksi sehingga pendapatan juga semakin besar.

2. Pada umumnya petani pembenihan ikan lele sangkuriang di desa Ngijo usianya tergolong usia tua (berpengalaman), pendidikannya tergolong cukup sehingga lebih cepat menguasai dan menerapkan teknologi yang diterima dengan luas kepemilikan usahatani yang tidak begitu luas $\pm 100 \mathrm{~m} 2$.

\section{DAFTAR PUSTAKA}

Anonim, 2016. Data Demografi Desa Ngijo Dalam Angka

Darseno. 2010. Teknik Pembenihan Lele Sangkuriang. Yogyakarta

Dardiani,Sary, 2010. Manajemen Pemanenan. Pusat Pengembangan Dan Pemberdayaan Pendidik Dan Tenaga Kependidikan Pertanian. 
Mantra. 2004. Filsafat Penelitian dan Metode Penelitian Sosial. Pustaka Pelajar. Yogyakarta

Mubyarto. 1995. Pengantar IImu Ekonomi Pertanian. LP3ES. Jakarta

Soekartawi, 2002. Teori Ekonomi Produksi dengan pokok nbahasan analisis fungsi Cobb-Douglas, Cetakan ke 3. Rajawali Pers. Jakarta.

Van den Ban AW, Hawkins HS 1999. Penyuluhan Pertanian. (terjemahan) Second Edition. Yogyakarta: Kanisius.
Yuvitasari, Desyta et all, 2017. Hubungan Faktor Sosial Petani dengan Penerapan Teknologi Budidaya Padi Hibrida di Kecamatan Pulung Kabupaten Ponorogo. E-Jurnal Agribisnis dan Agrowisata, vol 6 (3).

Sulaiman, Rasmahwati, 2018. Hubungan Luas Lahan Dan Tingkat Pendidikan Dengan Peningkatan Pendapatan Usahatani Padi Di Desa Topore Kecamatan. Papahan. Jurnal Agrifo, vol $3(2)$.

Sunarma, A. 2004. Peningkatan Produktifitas Usaha Lele Sangkuriang (Clarias sp.). Departemen Kelautan dan Perikanan, Direktorat Jendral Perikanan Budidaya, Balai Budidaya Air Tawar, Sukabumi. 